Aim of the study: In Poland testicular tumours are the most frequent cancer among men aged $20-44$ years. Testicular tumour incidence since the 1980s and 1990s has been diversified geographically, with an increased risk of mortality in Wielkopolska Province, which was highlighted at the turn of the 1980s and 1990s. The aim of the study was the comparative analysis of the tendencies in incidence and death rates due to malignant testicular tumours observed among men in Poland and in Wielkopolska Province.

Material and methods: Data from the National Cancer Registry were used for calculations. The incidence/ mortality rates among men due to malignant testicular cancer as well as the tendencies in incidence/death ratio observed in Poland and Wielkopolska were established based on regression equation. The analysis was deepened by adopting the multiple linear regression model. A $p$-value $<0.05$ was arbitrarily adopted as the criterion of statistical significance, and for multiple comparisons it was modified according to the Bonferroni adjustment to a value of $p<0.0028$ Calculations were performed with the use of PQStat v1.4.8 package. Results: The incidence of malignant testicular neoplasms observed among men in Poland and in Wielkopolska Province indicated a significant rising tendency. The multiple linear regression model confirmed that the year variable is a strong incidence forecast factor only within the territory of Poland. A corresponding analysis of mortality rates among men in Poland and in Wielkopolska Province did not show any statistically significant correlations. Conclusions: Late diagnosis of Polish patients calls for undertaking appropriate educational activities that would facilitate earlier reporting of the patients, thus increasing their chances for recovery. Introducing preventive examinations in the regions of increased risk of testicular tumour may allow earlier diagnosis.

Key words: epidemiology, testicular tumours, incidence, mortality.

Contemp Oncol (Pozn) 2016; 20 (1): 58-62 DOI: $10.5114 / w 0.2016 .58501$

\section{Malignant testicular tumour incidence and mortality trends}

\author{
Barbara Stawińska-Witoszyńska', Paulina Wojtyła-Buciora², \\ Barbara Więckowska ${ }^{3}$, Małgorzata Krzywinska-Wiewiorowska', \\ Małgorzata Gromadecka-Sutkiewicz ${ }^{4}$
}

${ }^{1}$ Department of Epidemiology, Poznan Medical University, Poznan, Poland 2Department of Hygiene, Poznan Medical University, Poznan, Poland ${ }^{3}$ Chair and Department of Informatics and Statistics, Poznan Medical University, Poznan, Poland

${ }^{4}$ Division of Medical Sociology, Poznan Medical University, Poznan, Poland

\section{Introduction}

Malignant testicular tumours belong to a group of rare neoplasms observed in men, constituting most frequently $1-1.5 \%$ of all malignant cancer diseases in this population [1-5]. They are, however, the most prevalent cancers among young men aged 15 to 45 years [2, 5-8].

More than $90 \%$ of all testicular tumours stem from germ cells (TGCT- testicular germ cell tumour), which may have the tissue of a pure seminoma (SEM - seminoma), a non-seminomatous tumour (NSGTC - non-seminomatous germ cell tumours), or belong to the mixed tumour type (MIX) [3, 7, $9,10]$. For this reason, the terms testicular tumour and testicular germ cell tumour are often used interchangeably [7].

In Poland testicular tumours constitute $1.6 \%$ of all malignant carcinomas in men, being the most frequent tumours among men aged 20-44 years [11]. Seventy-five per cent of such cases are seen in the age group 15 to 40 years [12]. The values of standardised malignant testicular cancer incidence rates in Poland towards the end of the $20^{\text {th }}$ and in the first decade of the $21^{\text {st }}$ century varied from 3.0 to $5.2 / 100,000$, whereas the mortality rates ranged from 0.45 to $0.62 / 100,000$. In the same period, incidence and mortality rates observed in Wielkopolska Province were higher (incidence ranging from 4.4 to $7.3 / 100,000$, mortality from 0.44 to $1.2 / 100,000$ ) [13]. The increased risk of mortality due to malignant sex-specific neoplasms, including testicular cancer, observed in the territory of Wielkopolska Province was emphasised already in the late 1980s/early 1990s [14].

\section{Aim of the study}

The aim of the study was the comparative analysis of the tendencies in incidence and death rates due to malignant testicular tumours observed among men in Poland and in Wielkopolska Province.

\section{Material and methods}

Data from the National Cancer Registry were used for calculations - crude rates and standardised incidence and mortality rates (direct standardisation method, using as standard the world standard population) due to testicular tumours observed among men in Poland and Wielkopolska Province in the period 1999-2011 [13]. Crude rates show the actual intensity of health-related problems without eliminating the effect of age on the value of those rates. Directly standardised rates bring the age structure of the two populations to the same pattern, giving an opportunity to compare the occurrence of diseases in different populations [14]. Directions of morbidity and mortality trends determined from the crude and standardised rates may vary. 


\section{Statistical methods}

The incidence and mortality rates among men due to malignant testicular cancer as well as the tendencies in incidence/death ratio observed in Poland and in the territory of Wielkopolska were established based on regression equation. The analysis was deepened by adopting the multiple linear regression model, which tested an independent impact of the year on the value of incidence and mortality rates, i.e. after adjusting the age variable (as the confounding factor) as well as the interrelationship of age and year. A $p$-value $<0.05$ was arbitrarily adopted as the criterion of statistical significance, and for multiple comparisons it was modified according to the Bonferroni adjustment to a value of $p<0.0028$. Calculations were performed on the basis of $\mathrm{PQStat}$ V1.4.8 package.

\section{Results}

The incidence among men with malignant testicular neoplasms, calculated on the basis of crude and standardised rates, in the territory of Poland and Wielkopolska Province showed a significant rising trend, confirming a (recognised for this type of tumour) lack of correspondence between the rising incidence and the age of this population of men (Figs. 1, 2) [8, 12].

The line gradients (a), indicating the rate of growth, were similar for Poland and the Province of Wielkopolska (crude rates: $p=0.6295$, standardised rates: $p=0.5596$ ).

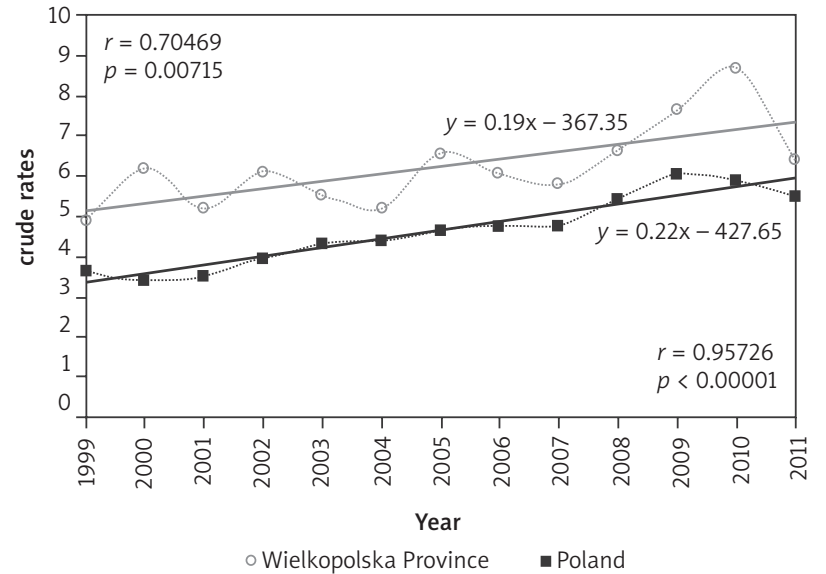

Fig. 1. Incidence trends among men with malignant testicular neoplasms in Poland and in Wielkopolska Province (crude rates) in the period of 1999-2011
Pearson's correlation coefficient ( $R$, the strength of linear correlation) differed significantly in the territory of Poland and Wielkopolska Province (crude rates: $p=0.0295$, standardised rates: $p=0.0337$ ). There was a stronger correlation, i.e. a more stable growth, observed in Poland than in Wielkopolska Province.

The multiple linear regression model used to thoroughly analyse the trends of malignant cancer incidence among men in Poland confirmed that the year is a strong incidence forecast factor ( $p=0.01998)$. However, the independent impact of year on incidence rates in Wielkopolska was not revealed (Table 1 ).

The studied interaction between year and age also turned out to be important (approaching the level of statistical significance, $p=0.09176$ ). This indicates that the increase in incidence is not steady in all age groups but pertains to young people to a greater extent (Table 2).

A corresponding age-group-specific analysis of mortality rates in the population of men in Poland and Wielkopolska Province did not reveal any statistically significant correlations (Figs. 3, 4).

The multiple linear regression model used in the thorough analysis of mortality rates among men due to malignant testicular neoplasms in Poland and in Wielkopolska Province indicated that the year variable is not an independent forecast factor (Table 3).

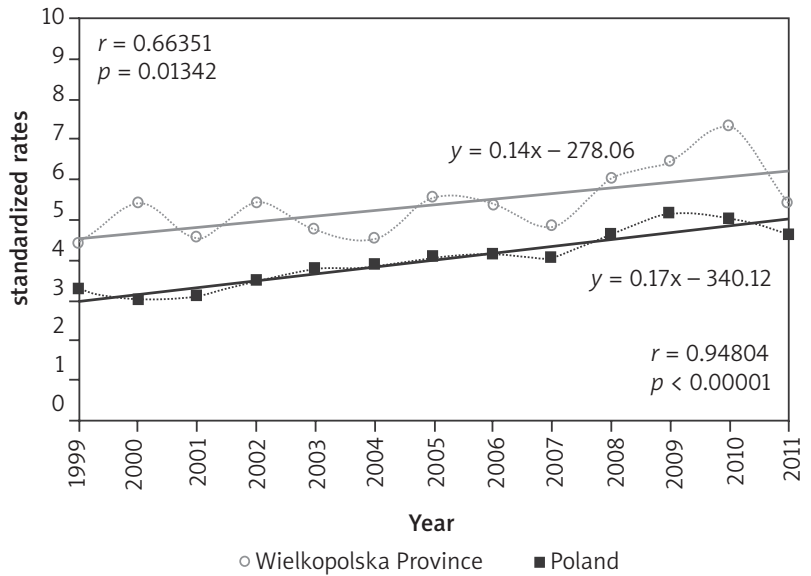

Fig. 2. Incidence trends among men with malignant testicular neoplasms in Poland and in Wielkopolska Province (standardized rates) in the period of 1999-2011

Table 1. Multiple regression model for the trends in malignant testicle tumour incidence among men in Poland and in Wielkopolska Province in the period 1999-2011

\begin{tabular}{|c|c|c|c|c|c|c|}
\hline & \multicolumn{3}{|c|}{ Poland } & \multicolumn{3}{|c|}{ Wielkopolska } \\
\hline & b & stat. $t$ & $p$-value & b & stat. $t$ & $p$-value \\
\hline Absolute term & -621.31 & -2.32 & 0.02095 & -514.28 & -1.30 & 0.19516 \\
\hline Year & 0.31 & 2.34 & 0.01998 & 0.26 & 1.32 & 0.18918 \\
\hline Age group & 41.69 & 1.69 & 0.09262 & 38.00 & 1.04 & 0.29978 \\
\hline Year*age group & -0.02 & -1.69 & 0.09176 & -0.02 & -1.05 & 0.29694 \\
\hline
\end{tabular}

$b$-multiple regression equation coefficient

stat. $t$-Student-t statistics in the multiple linear regression model

$p$-value-Student-t test probability 


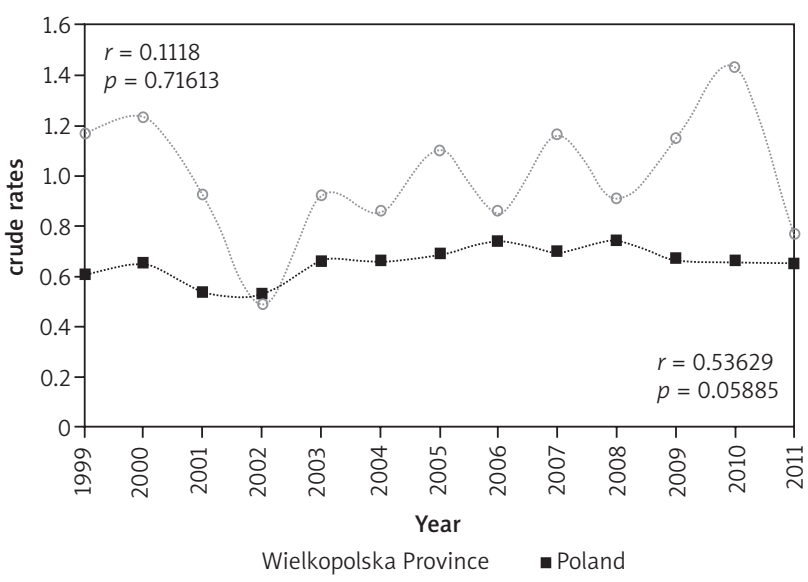

Fig. 3. Mortality rates among men due to malignant testicular neoplasms in Poland and in Wielkopolska Province (crude rates) in the period of 1999-2011

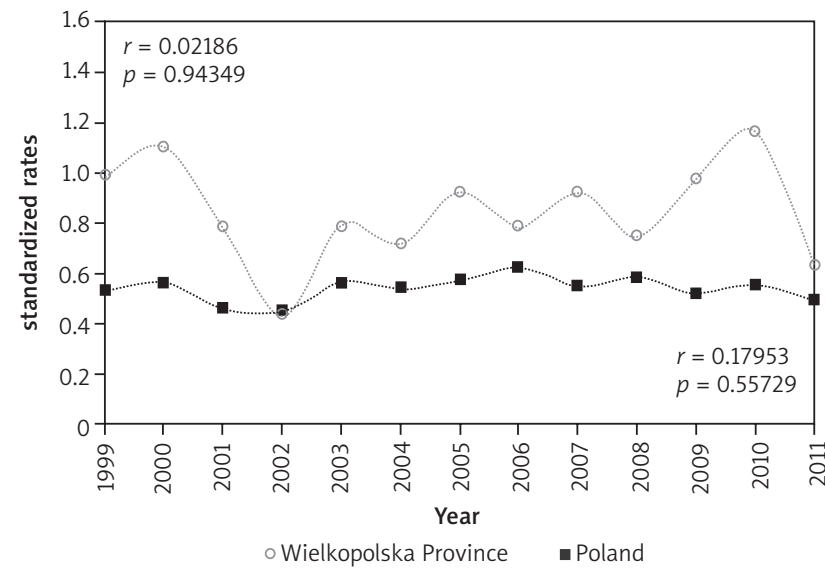

Fig. 4. Mortality rates among men due to malignant testicular neoplasms in Poland and in Wielkopolska Province (standardized rates) in the period of 1999-2011

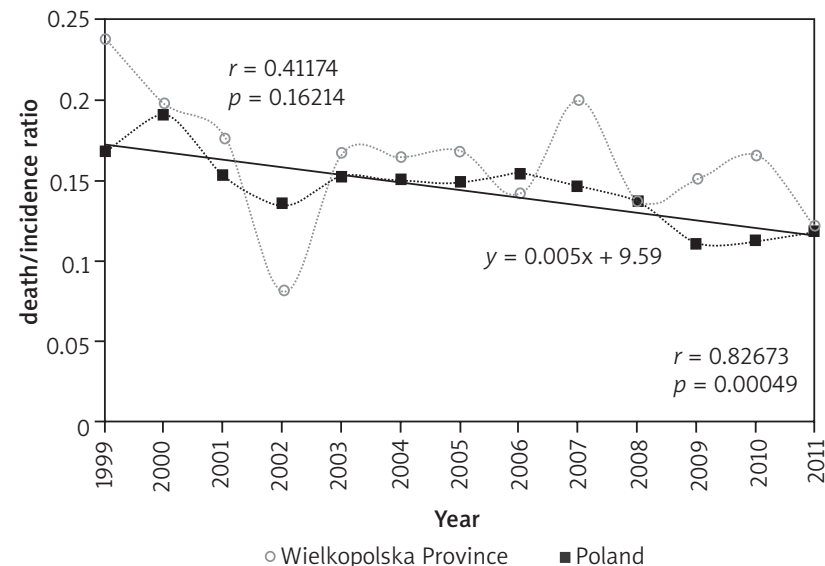

Fig. 5. The trend in death/incidence ratios in Poland and in Wielkopolska Province in the period of 1999-2011

Throughout the period subject to our study, a significantly decreasing tendency in the death/incidence ratio was observed only in the territory of Poland (Fig. 5).

\section{Discussion}

Geographical differences in the incidence due to testicular tumours had been observed for many years, the high-
Table 2. Analysis of age-group specific linear trend of malignant testicular neoplasms incidence among men in Poland and in Wielkopolska Province in the period 1999-2011

\begin{tabular}{lcccc}
\hline \multirow{2}{*}{ Age group } & \multicolumn{2}{c}{ Poland } & \multicolumn{2}{c}{ Wielkopolska } \\
\cline { 2 - 5 } & $r$ & $p$-value $^{*}$ & $r$ & $p$-value* \\
0-4 years & 0.35849 & 0.22905 & 0.24662 & 0.41663 \\
\hline 5-9 years & 0.16968 & 0.57945 & - & - \\
10-14 years & -0.03348 & 0.91353 & - & - \\
15-19 years & 0.73162 & 0.00448 & 0.08911 & 0.77222 \\
\hline 20-24 years & 0.82263 & 0.00055 & 0.03057 & 0.92102 \\
\hline 25-29 years & 0.94791 & $<0.00001$ & 0.63239 & 0.02038 \\
\hline 30-34 years & 0.93625 & $<0.00001$ & 0.34443 & 0.24914 \\
\hline 35-39 years & 0.88521 & 0.00006 & 0.17545 & 0.56643 \\
\hline 40-44 years & 0.68807 & 0.00933 & 0.28433 & 0.34644 \\
\hline 45-49 years & 0.70109 & 0.00759 & 0.45321 & 0.11987 \\
\hline 50-54 years & 0.63053 & 0.02087 & 0.23789 & 0.43383 \\
\hline 55-59 years & 0.07339 & 0.81169 & -0.08616 & 0.77958 \\
\hline 60-64 years & -0.06123 & 0.8425 & 0.3362 & 0.26137 \\
\hline 65-69 years & -0.16457 & 0.59109 & 0.21939 & 0.47143 \\
\hline 70-74 years & -0.52338 & 0.06643 & -0.4943 & 0.08597 \\
\hline 75-79 years & -0.7526 & 0.00299 & -0.3061 & 0.30909 \\
\hline 80-84 years & -0.52898 & 0.06306 & -0.2909 & 0.33492 \\
\hline 85+ years & -0.14252 & 0.64232 & -0.1342 & 0.66204 \\
\hline
\end{tabular}

$r$-Pearson's correlation coefficient

p-value*Pearson's correlation

The significance level for the $p$ value in the table above has been modified according to Bonferroni adjustment and equals 0.0028

est incidence having been noted since 1940 in white men in the USA. For the subsequent 40-50 years the incidence was rising in western European countries [15].

In the $21^{\text {st }}$ century the highest testicular tumour incidence has been observed in the countries of western and northern Europe as well as Australia and New Zealand, slightly lower incidence has been noted in North America, southern Europe, and Central America, and the lowest in Asia and Africa [3, 4, 7, 8, 16]. According to prediction, by 20251 in 100 men under 75 years of age will be diagnosed with this illness in Norway, Croatia, and Slovenia, the highest risk countries in Europe [17].

Malignant testicle tumour incidence among Polish men has increased by a factor of three in the past three decades (in 2011 there were almost 1100 noted cases) [11]. In the 2008 the incidence reached the level of 3.5/100,000 and was lower than the average level for EU countries $(6.1 / 100,000)$ but higher than the average for Central and Eastern Europe (2.6/100,000 - data from 2008) [8, 11]. Out of $27 \mathrm{EU}$ countries Poland was ranked eighth with respect to testicular cancer incidence rates among men, the lowest incidence rates having been observed in Greece, Romania, and Portugal, whereas the highest were noted in Denmark, Slovenia, and the Czech Republic [8].

Within the period subject to our study, the standardised testicular cancer incidence rates in men living in Wielkopolska were higher than the Polish average values, and in 2009 the incidence rate exceeded the average value for EU countries $-6.0 / 100,000$ [11].

The described growing tendency in the testicular tumour incidence among men in Poland encompassed 
Table 3. Multiple linear regression model for mortality rates among men due to malignant testicular neoplasms in Poland and in Wielkopolska Province in the period 1999-2011

\begin{tabular}{lcccccc} 
& \multicolumn{3}{c}{ Poland } & \multicolumn{3}{c}{ Wielkopolska } \\
\cline { 2 - 7 } & $\mathbf{b}$ & stat. $\boldsymbol{t}$ & $\boldsymbol{p}$-value & $\mathrm{b}$ & stat. $t$ & $p$-value \\
Absolute term & -44.68 & -0.77 & 0.44482 & -55.45 & -0.30 & 0.76471 \\
Year & 0.02 & 0.76 & 0.44560 & 0.03 & 0.30 & 0.76472 \\
Age group & 6.39 & 1.18 & 0.23732 & 9.73 & 0.57 & 0.56993 \\
Year *age group & 0.00 & -1.17 & 0.24451 & 0.00 & -0.56 & 0.57525
\end{tabular}

$b$-multiple regression equation coefficient

stat. $t$-Student-t statistics in the multiple linear regression model

p-value-Student-t test probability

three increasing time trends observed in three age groups: among children (0-19 years), young adults (20-44 years), and middle-aged men (45-64 years), while in the group of 20-44-year-olds the incidence rate grew most rapidly [11].

In the period of 1999-2011, both the standardised and the crude malignant testicular cancer incidence rates indicated a significantly growing tendency in Poland and in Wielkopolska Province, which confirmed the specificity of testicular cancer incidence among men and its bimodal distribution [12]. The increasing trend in testicular tumour incidence observed in Poland was compliant with the time trends in many other countries [7, 8, 10, 17-19].

In the territory of Poland, an increasing incidence trend was observed in the four subsequent age groups, encompassing jointly men aged 20-39 years. In Wielkopolska Province, the growing incidence among young men has not shown any statistical significance.

The reasons for the growing malignant testicular cancer incidence that has been observed for the past 50 years all over the world, mostly in developed countries, as well as the differences in the course of its trends between various countries, remain unknown [7, 20]. The recognised risk factors, e.g. cryptorchidism, former testicular malignancy, intratubular germ cell neoplasia, family history of testicular cancer, being exposed to a high level of motherly oestrogens in utero, and fertility disorders, as well as better diagnostics and more precise statistics of incidence rates do not fully explain the diversity of trends $[5,8,20]$.

More than $90 \%$ of testicular tumours stem from germ cells. There is no doubt that the ethnical background is one of the single, subordinate aetiological factors having an impact on the development of these tumours (the incidence is higher among white men living in industrialised countries, especially in northern Europe). The discrepancies observed all over the world, however, result from in teractions between genetic factors and harmful impacts of the environment [3-5, 7, 8, 20].

The relationship between perinatal risk factor, congenital abnormalities, and the onset of the disease at a young age suggest that tumour formation may start in the womb, and its further development may be determined by such aspects as life style - diet, lack of physical activity, the type of work performed, or being expose to harmful chemical substances $[5,7,20]$. Due to contradictory results of studies, the increase in the incidence among some men associated with the specificity of work they do and the exposure to such harmful factors as high temperature in the scrotum, lack of physical activity due to extended sitting time, or the impact of electromagnetic fields require further detailed research $[5,7]$. Just how little is known about testicular cancer risk factors can be seen from the results of research confirming an increase or a decline in risk of cancer caused by the same factors and sometimes negating their relationship with carcinogenesis. This refers to such aspects as body mass index (BMI), height, and physical activity [5, 7, 20]. Consumption of marihuana, exposure to high temperatures, and the potential impact of some viruses on the development of testicular tumours must also be confirmed in further epidemiological studies [7, 21].

Testicular cancer mortality rates, similarly to incidence rates, have revealed geographical diversity, characterised by the highest values observed in Central America, Central and Eastern Europe, and Western Asia and the lowest in Australia and Eastern Asia [16]. Starting from the 1970s, mortality rates have been decreasing significantly in most western and northern European countries, whereas the decline in mortality rates in central and eastern European countries started later (in the 1980s) and was considerably smaller. Also, the level of mortality in the countries of Southern Europe is higher than in the countries of western and northern Europe [22, 23].

Positive tendencies in mortality rates, associated with the improvements in diagnostics and chemotherapy efficiency (the inclusion of cisplatin into treatment regimens) that have been observed in most European countries in recent decades correspond to those reported in the USA [23, 24].

The mortality caused by testicular tumours in men increased in Poland until the beginning of the 1990s, after which there was a change in trends, with a significant decline. Nevertheless, the mortality rates are still slightly higher than the average rates in EU countries. The growing tendency was persistently the longest (until the beginning of the $21^{\text {st }}$ century) among men aged 20-24 years [11]. In the period 1999-2011 there were no significant changes in mortality rates observed for the population of men in Poland and in Wielkopolska Province.

Testicular cancer is one of the most easily preventable malignancies, and early diagnosis and radical treatment increase the chance of survival of a significant proportion of patients [7, 14, 24]. Prognosis depends on the histological type of cancer, with the best being in the case of seminoma, which appear most often in men aged 35-40 years, and non-seminomatous tumours, occurring mostly among 
25-29-year olds, whereas the forecast related to non-seminomatous germ cell tumours is the worst [7, 19, 25].

\section{Summing up}

Testicular tumour incidence rates in Poland are among the lowest in Europe and its growth corresponds to the tendencies evident in other countries. What is worrying is the fact that there has been a significant increase in incidence in the age group 20-39-year-olds as well as a lack of any significant declining trend in the mortality rate, which is slightly higher than the average for EU countries. A positive observation is the significant declining tendency in the death/incidence ratio. In the territory of Wielkopolska there has been an observed growing tendency of incidence, higher in comparison with the national average.

A high percentage of patients in Poland, whose tumours at the time of diagnosis are larger than $5 \mathrm{~cm}$ in diameter, or whose testicles are fully occupied by malignancy, indicate a long period of development of the disease prior to the diagnosis. Appropriate educational programs can contribute to earlier reporting of patients with a lower severity of the disease, thus increasing their chances of recovery [9]. Introducing preventive examinations in regions, such as Wielkopolska, characterised by increased risk of testicular tumour for boys and men aged 10-35, who for the previous five years have been treated for cryptorchidism, migrating, atrophic, hypotrophic testicles, Klinefelter syndrome, infertility, and testicular cancer, following the pattern of procedures adopted in Kraków, may allow earlier diagnosis [26]. In view of the fact that the increase of testicular tumour incidence in Poland begins among men from the age of 20, a thorough periodical check-up examinations of adolescents, including the assessment of sexual maturity, should be emphasised. The question is whether such examinations should be performed at school.

\section{The authors declare no conflict of interest.}

\section{References}

1. Vasdev N, Moon A, Thorpe AC. Classification, epidemiology and therapies for testicular germ cell tumours. Int J Dev Biol 2013; 57: 133-9.

2. Shanmugalingam T, Soultat A, Chowdhury S, Rudman S, Van Hemelrijck M. Global incidence and outcome of testicular cancer. Clin Epidemiol 2013; 5: 417-27.

3. Mikuz G. Hodenkrebs - eine Frage der Geographie? Pathologe 2014; 35: 211-17.

4. Manecksha RP, Fitzpatrick JM. Epidemiology of testicular cancer. BJU Int 2009; 104 (9 Pt B): 1329-33.

5. Yousif L, Hammer GP, Emrich K, Blettner M, Zeeb H. Occupational risk factors for testicular cancer: a registry-based case control study in Rhineland Palatine - Germany. Ger Med Sci 2013; 11: Doc16. doi: 10.3205/000184.

6. Rusner C, Streller B, Stegmaier Ch, Trocchi P, Kuss O, McGlynn KA, Trabert B, Stang A. Risk of second primary cancers after testicular cancer in East and West Germany: a focus on contralateral testicular cancers. AJA 2014; 16: 285-89.

7. McGlynn K, Trabert B. Adolescent and adult risk factors for testicular cancer. Nat Rev Urol 2012; 9: 339-49.

8. Cancer Research UK. Testicular cancer incidence statistics. Available at: http://www.cancerresearchuk.org/cancer-info/cancerstats/ types/testis/, accessed on June 6, 2014.
9. Oszukowska E, Różański EW, Jakubiak-Wielganowicz M, Sosnowski M, Kordek R, Kula K. Rozpoznanie histopatologiczne i markery nowotworowe we krwi a zaawansowanie kliniczne guzów jądra wywodzących się z komórek płciowych. Urologia Polska 2008; 61 Suppl. 1: 50-51.

10. Rusner C, Trabert B, Katalinic A, Kieschke J, Stang A; Network of German Cancer Registries (GEKID). Incidence patterns and trend of malignant gonadal and extragonadal germ cell tumors in Germany, 1998-2008. Cancer Epidemiol 2013; 37: 370-3.

11. Epidemiologia - dane statystyczne KRN, available at website http://onkologia.org.pl./k/epidemiologia, accessed on June 5, 2014.

12. Didkowska J. Epidemiologia nowotworów złośliwych w Polsce. In: Podstawy onkologii klinicznej. Mader J (ed.). CMKP, Warszawa 2011; 5-17.

13. Wojciechowska U, Didkowska J. Zachorowania i zgony na nowotwory złośliwe w Polsce. Krajowy Rejestr Nowotworów, Centrum Onkologii - Instytut im. Marii Skłodowskiej-Curie. Available at: http://onkologia.org.pl/raporty/, accessed on June 5, 2014.

14. Zatoński W, Tyczyński J (eds.). Nowotwory złośliwe w Polsce w 1995 roku. Centrum Onkologii - Instytut im. M. Skłodowskiej-Curie, Warszawa 1998.

15. Holmes L Jr, Escalante C, Garrison O, Foldi BX,Ogungbade GO, Essien E J, Ward D. Testicular cancer incidence in the United States (1975-2004): Plateau or shifting racial paradigm? Public Health 2008; 122: 862-72.

16. Rosen A, Jayram G, Drazer M, Eggener SE. Global Trends in Testicular Cancer Incidence and Mortality. European Urology 2011; 60: 374-79.

17. LeCornet C, Lortet- Tieulent J, Forman D, Beranger R, Flechon A, Schuz J, Bray F. Testicular cancer incidence to rise by $25 \%$ by 2025 in Europe? Model-based predictions in 40 countries using population-based registry data. Eur J Cancer 2014; 50: 831-9.

18. McGlynn KA, Devesa SS, Sigurdson AJ, Brown LM, Tsao L, Tarone RE. Trends in the Incidence of Testicular Germ Cell Tumors in the United States. Cancer 2003; 97: 63-70.

19. Llanes Gonzalez L, Lujan Galan M, Rodriguez GN, Garcia Tello A, Berenguer Sanchez A. Trends in the incidence of testicular germ cell cancer in a 300.000 inhabitants Spanish population (19912005). Actas Urol Esp 2008; 32: 691-5.

20. McGlynn KA, Cook MB. Etiologic factors in testicular germ cell tumors. Future Oncol 2009; 5: 1389-402.

21. Yousif L, Hammer GP, Blettner M, Zeeb H. Testicular cancer and viral infections: A systematic literature review and meta-analysis. J Med Virol 2013; 85: 2165-75.

22. Znaor A, Bray F. Thirty year trends in testicular cancer mortality in Europe: gaps persist between the East and West. Acta Oncol 2012; 51: 956-8.

23. Bosetti C, Bertuccio P, Chatenoud L, Negri E, La Vecchia C, Levi F. Trends in mortality from urologic cancers in Europe, 1970-2008. European Urology 2011; 60: 1-15.

24. Cooper DE, L'esperance JO, Christman MS, Auge BK. Testis cancer: a 20-year epidemiological review of the experience at a regional military medical facility. J Urol 2008; 180: 577-81.

25. Valsero Herguedas ME, Pascual Samaniego M, Garcia Lagarto E, Martín Martin S, Muñoz Moreno MF, Cortiñas Gonzalez JR. Testicular cancer: our experience after 10 years. Arch Esp Urol 2012; 65: 467-75.

26. Miejski Program Ochrony Zdrowia [Public Health Protection Programme]: Zdrowy Kraków 2010-2012. Health Protection Office at the Town Hall in Kraków.

\section{Address for correspondence}

\section{Barbara Stawińska-Witoszyńska}

Department of Epidemiology

Poznan Medical University

Dąbowskiego 79

60-529 Poznan, Poland

e-mail: bwitoszynska@hoga.pl

Submitted: 2.12 .2014

Accepted: $\quad$ 15.10.2015 